\title{
ODR NEWS APRIL 2014
}

\section{UK Forms ODR Advisory Group}

The Civil Justice Council (a public body with responsibility for overseeing and coordinating the modernization of the civil justice system of England and Wales) has formed an ODR Advisory Group tasked to produce a Report in nine months on the introduction of ODR into the civil justice system for civil claims up to $£ 20,000$ in value.

Richard Susskind, the Head of this new Advisory Group (as well as IT adviser to the Lord Chief Justice, and president of the Society for Computers and Law) wrote an article in The Times which covers ODR, and which concludes:

ODR offers the promise of robust and yet radically less costly dispute resolution. While today's lawyers and policymakers may find it alien or outlandish, few of them belong to the internet generation. Tomorrow's citizens, for whom working and socialising online is second nature, are likely to regard ODR as a wholly natural facility, much more so perhaps than conventional courts.

<www.thetimes.co.uk/tto/law/columnists/article4070943.ece>

\section{AAA Chooses ODR for Its Largest Volume Case Load}

The American Arbitration Association (AAA) has decided to partner with Modria.com to build a new ODR platform to manage AAA's New York No Fault (NYNF) case load. This system will support more than 100,000 cases annually, providing new online tools to appellants and insurance carriers, and new case management tools to AAA staff and neutrals.

The AAA New York Insurance ADR Center will go live in the second quarter of this year, and will allow appellants and their attorneys to file disputes online with just a browser and an Internet connection. All parties will be able to get ondemand status updates on pending cases anytime, keeping all participants aware of progress. The new platform will provide AAA staff with rich case and document management, and new hearing scheduling tools, supporting their ongoing commitment to process optimization and continuous process improvement. New secure online communication tools will allow parties to communicate directly with AAA staff, and with each other, adding additional efficiency to the overall resolution process.

This new platform will accelerate case processing, ensure secure and transparent communication between parties, and increase convenience for AAA and its customers. It will support conciliation (mediation), arbitration and master appeal processes. Insurance carriers, applicants and general counsel will save valuable time, while increasing transparency and access for all parties. 
$<$ www.prnewswire.com/news-releases/american-arbitration-associationselects-modria-to-power-new-york-no-fault-caseload-248543191.html>

\section{New European Online Mediation Resource}

A coalition of several groups in Europe have teamed up to launch <http://goto mediation.eu>, a website to promote the awareness and use of Mediation in cross border B2B disputes - both for preventing and resolving disputes. The site also aspires to offer affordable cross-border mediation services precisely tailored to the specific requirements of cross border-business Mediation.

The site will assist individual disputants in deciding whether Mediation is the right resolution path. If Mediation is appropriate, the site will organize the Mediation process. Gotomediation.eu offers an independent and trusted service for dealing with B2B disputes. Through the network of several European Chambers of Commerce and Mediation Centres the site is able to refer disputants to the appropriate contact, provide necessary legal information, and help to find a suitable, highly qualified and experienced business mediator.

As the site explains, the requirements for mediators who deal with crossborder Mediation are high. The mediator needs to have an understanding of the legal situation in the countries of the parties as well as the cultural differences. Eliminating language barriers and misunderstandings caused by cultural patterns of behavior is as important as to endorse the request to make the content of a written agreement resulting from Mediation enforceable. Gotomediation.eu organizes a regular exchange of knowledge and experiences between our mediators and institutions, so as to ensure compliance with training standards and legal developments at European level to ensure a high quality of service.

To learn more, visit <http://gotomediation.eu>.

\section{UNCITRAL ODR Working Group Hears from Private Sector Experts}

Working Group III of UNCITRAL met at the United Nations in New York City from 24-28 March 2014. This meeting was preceded by a meeting of ODR experts (both commercial and academic) from the private sector who offered perspective on the deliberations to date. Recently the Working Group has been hampered by disagreements among the participating State members around whether the rules being designed should provide for binding or non-binding consumer outcomes. In light of these continuing disagreements, the Expert Group released a consensus statement prior to the Working Group meeting that made several observations, including:

- The expert group believes that both consumer and business groups around the world are unanimous in seeking fair, proportionate, effective, online, cross-border redress for low value cross-border disputes. As a result, ODR is already happening, and it will continue to grow regardless of the actions of the Working Group. That said, the experts are unanimous in hoping that the 
Working Group will be able to issue rules urging expanded global access to quality ODR.

- It is vital for consumers and small to medium size business alike to address the problem of cross-border consumer redress and the private sector is stepping in to provide manifold solutions to this problem. Market-based approaches will provide the best solutions for this problem. These marketbased approaches will require a lot of experimentation and evolution to get it right. As such, the rules issued by the Working Group should not be too prescriptive, because they may hinder innovation required to solve this problem over the longer term.

- ODR administrators, marketplaces, and payment providers want the flexibility to design, build, and deploy both non-binding and binding ODR systems. Each ODR system designer can later decide which design is a better fit with their specific needs and relevant legal environment. The Working Group should not spend any more time debating which design is better or preferred.

The ODR Working Group from UNCITRAL will next meet in Vienna near the end of 2014. For more information on the Working Group, and a draft copy of its proposed ODR guidelines, visit <www.uncitral.org/uncitral/commission/working groups/3Online_Dispute_Resolution.html>

\section{New ODR Providers: Rezoud, Arbitration Resolution Services (ARS), and Youstice}

Three new ODR service providers have launched, two in Florida and one in Prague.

Rezoud (<www.rezoud.com $>$ ) is an industry leading Technology, Dispute Resolution and Education company focused on the international Dispute Resolution Industry. Based on more than three years and 10,000 hours of research, Rezoud has announced a series of new products and services to the Dispute Resolution marketplace: Technology-enhanced Dispute Resolution $\mathrm{TeDR}^{\mathrm{TM}}$, a new conflict resolution process methodology built around having the parties communicate more directly via Facilitated Negotiation leveraging fixed processes enhanced by technology; Settle-Now ${ }^{\mathrm{TM}}$, offering a Unified Communications Eco System, Enhanced Case-Management with video-conferencing plug-ins and proprietary settlement algorithms centered on Dynamic database processing, Big Data, settlement calculators and integration with court e-filing systems; Rezoud Academy announces a new three course online certificate in Corporate Dispute Resolution in partnership with the University of South Florida - St. Petersburg; and Family$\operatorname{Settle}^{\mathrm{TM}}$, a new system to simplify divorce into a user friendly, next generation collaborative divorce process bundled into a single cutting edge system.

Rezoud is located in Tampa Bay, Florida - but has also opened a European Headquarters, located in Paris. A video interview with the CEO is available here: <www.youtube.com/watch?v=L8ofE14X108>. 
Founded by experts in dispute resolution and technology, Arbitration Resolution Services, Inc. (ARS, located at <www.arbresolutions.com>) has launched a service called Complete system for Online Dispute Resolution, or C-ODR. Combining its unique proprietary technology with a roster of industry professionals, ARS offers services in the Alternative Dispute Resolution (ADR) and legal areas that allow for accurate, efficient and affordable dispute resolution services for all, according to its leadership.

At the core of ARS services is its proprietary Arb-IT system, which guides parties through the mediation or binding arbitration process. The system also enables users to submit their claims and supporting evidence electronically. The case is then assigned to a highly experienced, impartial litigation attorney, who serves as the parties' personal judge in a secure and private forum. The company's programs include disputes involving businesses and individuals, disputes involving businesses and disputes involving physical damage to real or personal property.

ARS is based in Coral Gables, Florida. For more information, visit <www.arbresolutions.com>.

Youstice (<www.youstice.com〉) is an open, globally available service in the area of low value customer claims. Youstice aims to interconnect ODR stakeholders all over the world - buyers and sellers, ODR providers, consumer centers, trustmarks, and online marketplaces. Every stakeholder will be able to communicate in their own language via the Youstice platform.

Youstice is holding media days in UK, France and Germany to introduce the project and partners in May 2014, with an official launch of following on 11 June 2014 in London.

The company is inviting ODR experts to become Youstice accredited ODR providers and/or ODR trainers for neutrals. Youstice considers ODR providers to be partners, and so provides services to providers at a very low cost. In addition, Youstice guarantees that ADR professionals get paid fees from the parties to each case. Youstice also makes participation very easy for neutrals, making online caseloads easy to maintain alongside other projects.

Youstice is based out of Prague, in the Czech Republic. Trials of the beta version are available on the Youstice web site (<www.youstice.com $\rangle$ ).

Colin Rule 


\section{Order Form}

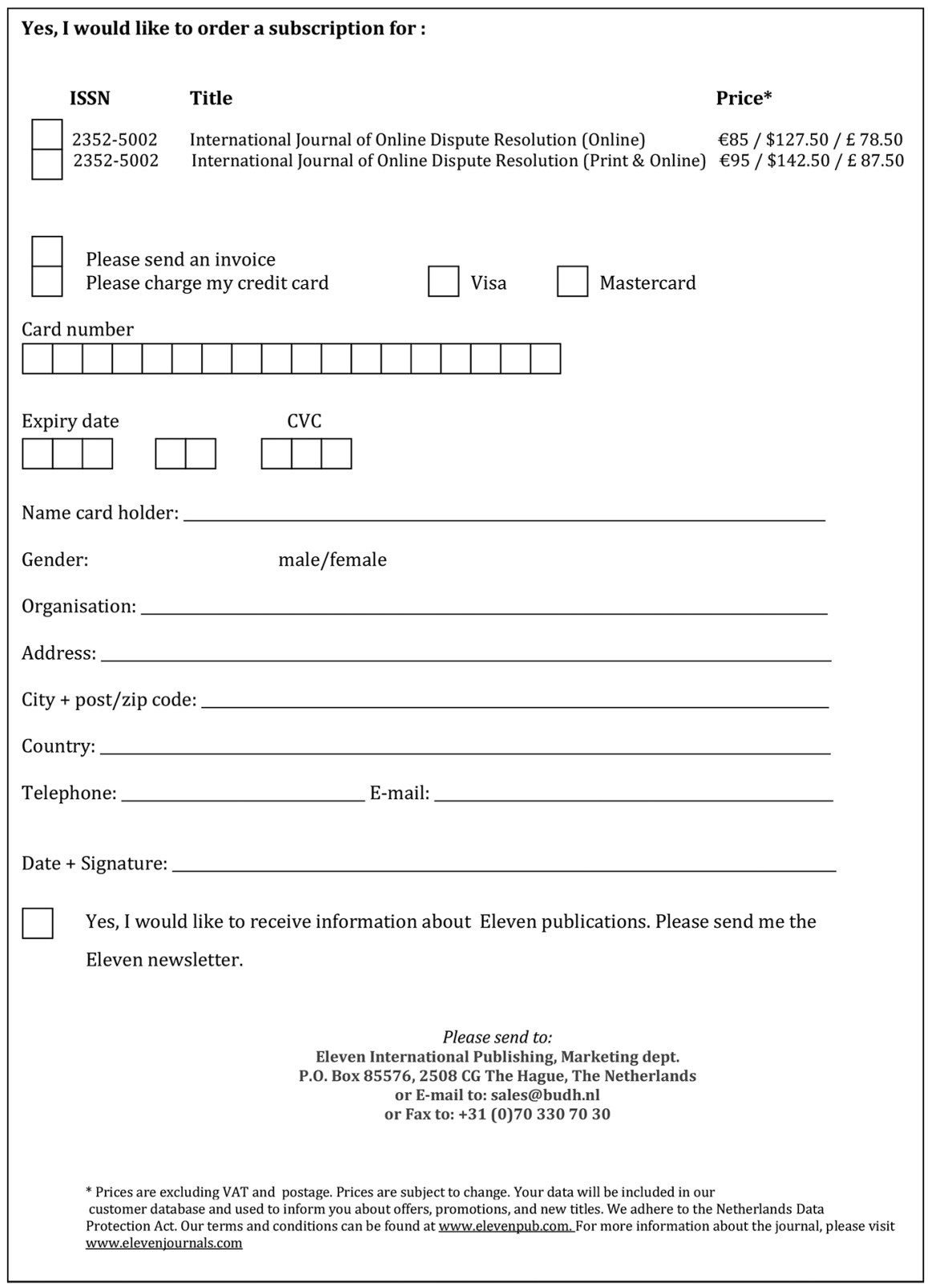

